\title{
Onesimus, Philemon's runaway slave boy: A brief liberation-theological exegesis of Philemon vv. 8-18 in the Nigerian context
}

\begin{tabular}{|c|c|}
\hline \multicolumn{2}{|c|}{$\begin{array}{l}\text { Authors: } \\
\text { Chris U. Manus } \\
\text { Chibuzo I. Nwanguma }{ }^{1,2,3}\end{array}$} \\
\hline \multicolumn{2}{|c|}{$\begin{array}{l}\text { Affiliations: } \\
\text { 'Department of Theolog } \\
\text { Religious Studies, Natior } \\
\text { University of Lesotho, } \\
\text { Roma, Lesotho }\end{array}$} \\
\hline \multicolumn{2}{|c|}{$\begin{array}{l}{ }^{2} \text { Department of New } \\
\text { Testament and Related } \\
\text { Literature, Faculty of } \\
\text { Theology and Religion, } \\
\text { University of Pretoria, } \\
\text { Pretoria, South Africa }\end{array}$} \\
\hline \multicolumn{2}{|c|}{$\begin{array}{l}{ }^{3} \text { Department of Philosophy } \\
\text { and Religion, Faculty of } \\
\text { Humanities, Management } \\
\text { and Social Sciences, Mountain } \\
\text { Top University, Ibafo, Nigeria }\end{array}$} \\
\hline \multicolumn{2}{|c|}{$\begin{array}{l}\text { Research Project Registration: } \\
\text { Project Leader: Z. Dube } \\
\text { Project Number: } 13339746\end{array}$} \\
\hline \multicolumn{2}{|c|}{$\begin{array}{l}\text { Corresponding author: } \\
\text { Chris Manus, } \\
\text { manuschris3@gmail.com }\end{array}$} \\
\hline \multicolumn{2}{|c|}{$\begin{array}{l}\text { Dates: } \\
\text { Received: } 31 \text { Mar. } 2020 \\
\text { Accepted: } 02 \text { Oct. } 2020 \\
\text { Published: } 27 \text { July } 2021\end{array}$} \\
\hline \multicolumn{2}{|c|}{$\begin{array}{l}\text { How to cite this article: } \\
\text { Manus, C.U. \& Nwanguma, } \\
\text { C.I., 2021, 'Onesimus, } \\
\text { Philemon's runaway slave } \\
\text { boy: A brief liberation- } \\
\text { theological exegesis of } \\
\text { Philemon vv. 8-18 in } \\
\text { the Nigerian context', } \\
\text { HTS Teologiese Studies/ } \\
\text { Theological Studies } \\
\text { 77(1), a6016. https://doi. } \\
\text { org/10.4102/hts.v77i1.6016 }\end{array}$} \\
\hline \multicolumn{2}{|l|}{ Read online: } \\
\hline 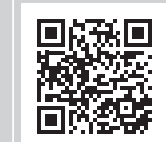 & $\begin{array}{l}\text { Scan this QR } \\
\text { code with your } \\
\text { smart phone or } \\
\text { mobile device } \\
\text { to read online. }\end{array}$ \\
\hline
\end{tabular}

Slavery is one of the life's most odious vices ever experienced in human history. Its abhorrent nature is such that even those involved in the enslavement of others often detest the cruel phenomenon. The Nigerian ruling elite seems to feign ignorance of the hidden agenda of some modern slavers in their employment, but the Nigerian Christian population has come to acknowledge the ignoble policies that are slavery in disguise. Their cry for redemption has been by praying for Nigeria in distress, numerous crusades, and praising and worshiping sessions dedicated to the Lord of peace and salvation. However, many people have become frustrated, as they feel these activities are tedious, outlandish and irrelevant. For them, action is the master key to solving this national ordeal or hardship. This situation is exacerbated by the ever-increasing tension and sour relationship between Muslims and Christians in Nigeria, where it is becoming apparent that there is no political will on the part of the ruling class to promote harmonious living, but that they would rather prefer to gloss over and pay lip service to the enslavement and oppression of the Christian population. The letter of Paul to Philemon, especially verses $8-18$, is a relevant biblical resource that we find useful to address the situation. In order to do so, to the best of our ability, we have examined and outlined the undisputed and underlying sensitive levels of religious intolerance, which are making Nigerian Christians to become an endangered species in their fatherland. Indeed, the situation calls for an urgent deployment of the biblical principles that are rooted in, and derived from, the liberationtheological approach to doing contextual biblical exegesis. This study makes use of the liberation-theological approach to argue that liberation is ad rem and considered a relevant tool for this study. It was observed in this study that the current situation in Nigeria is nothing less than slavery and can hardly be described otherwise. If slavery or enslavement of any person, group or ethnic or indigenous people include the overt denial of their God-given freedom, accountability, good governance and social justice that make up the hallmarks of a democracy, then there is enslavement.

Contribution: This study contributes to authentic Christian existence and enhancement of principles such of love, justice and solidarity in the Nigerian public domain, as that would render enslavement agenda existing in Nigeria a contradiction. It endorses the values of peace, justice and maintenance of strong institutions.

Keywords: enslavement; hidden agenda; intervention; manumission; agape; harmonious living; national cohesion.

\section{Introduction}

Until very recently, slavery was a common practice in human history. In the ancient world, its acceptability was endemic, especially in the Roman Empire in which Christianity was born and developed (Boer 1976:2). In this Empire, slaves constitute about 50\% of the population at that time (Ogbonna 2012). This culture, as it were, endured till the 18th and the 19th centuries. By that time, slavery was a way of showcasing one's wealth and status in that old society, as was known amongst African and Nigerian ancient kingdoms in particular. As noted by Hildebrandt (1981:75), to understand the problem of slavery faced by Africa, Europe, North and South America in the 18th and 19th centuries, it is essential to realise that there were two concepts of slavery, in practice, at that time: 'limited' and 'total' slavery. The 'limited slavery' practised amongst Africans included victims who were essentially war captives and convicted criminals. This group could buy their

Copyright: () 2021. The Authors. Licensee: AOSIS. This work is licensed under the Creative Commons Attribution License. Note: Special Collection: Africa Platform for NT Scholars, sub-edited by Ernest van Eck (University of Pretoria). 
freedom with time. There was another category, the 'total slavery', which was practised amongst the Arabs and the Europeans. Such slavers had always bought slaves who were domiciled at their residences and served the household for lifetime. Whilst limited slavery practised amongst Africans could be identical to what was obtainable amongst the Jews of the Old Testament (OT) times (cf. Ex 21:1-21), the latter practised amongst the Arabs and the Europeans could somewhat be similar to the culture that prevailed in the New Testament (NT) era where the feudal emperors and their counterpart merchants lorded it over the masses (Mk 10:44; Jn 8:34-35; Ac 16:16, 19). Paul, in Philemon, initiated its abolition by appealing to common societal values system universally recognised and imbedded in the Golden Rule and Christian ethics (Jeal, Harry \& Maier 2015:14), even though in other passages (cf. Eph 6:5-9; 1 Tim 6:1-2; Tit 2:9-10), he wrote as if he endorsed slavery where he proffered solutions as to how slaves could live happily 'within their tragic situation' (cf. Col 3:22-24; Nwanguma 2018:51). Besides, it is noted that the Arabian Muslims and their European counterparts brought slavery to Africa in the 18th and 19th centuries through the Trans-Atlantic trade routes and colonialism (Falk 2011:96), and from thence they took slavery to a monstrous level in the African continent (Hildebrandt 1981:76). This slave culture and enslavement of Arabian Muslims have not really been obliterated from heartless Muslim rulers (ElombahNews 2020) in Nigeria. In similarity, they share their religion and culture, and as they still hold themselves as 'born to rule', a notion derived from a religious ideology that is traceable to Arab traditions and mindset.

The present trend of oppression and violation of the freedom of indigenous peoples in Nigeria is quite more identical to the idea of Arab enslavement where, although in a democratic dispensation, all actions point to gross favouritism to a particular tribe, the Fulanis (Danjuma 2020). The phenomena of slavery and slavedom are glaringly noticeable across all tiers of government, as well as in other sectors, including homes. Appointments are, for example, lopsided as they are made in favour of the Muslims and the Fulanis, in particular (ElombahNews 2020). The obvious nature of this slavery mentality is so much that over six decades after political independence, people still work in fear as though they are under a slave master in their own fatherland. The imposition of hate speech Bill, for instance, which is meant to be used against any person who dares to speak against the draconian rule in Nigeria (Nigeria info 99.3 FM, Aug 21, 2020), is contrary to the Pauline notion where any person who is set free from slavery no longer acts 'as a slave, but better than a slave, as a dear brother...' (Phlm 16). The need to dismantle the continuing waves of slavery, nepotism and enslavement to make way for the emergence of a true egalitarian society is the thrust of this article.

\section{Context of interpretation}

The context from which we read the story of the enslavement of Onesimus is a facsimile to what manifests itself in today's
Nigeria. We wish to join the Christian Association of Nigeria (CAN) to examine and outline the undisputed and sensitive levels of religious intolerance, which makes 'Nigerian Christians be endangered species in their Fatherland' (Internet Post to Luke Ijezie, 28 December, 2019). The Nigerian Government has failed to implement effective strategies to prevent or stop the reckless and senseless violence that is prevailing in Nigeria or to hold the perpetrators accountable (Message to Nigerians from Amb Prophet Isa El-Buba, March 2020).

The leadership of the CAN has constantly reported such dastardly happenings to President Muhammadu Buhari in a number of meetings with him to prefer to see the whole country as his constituency and to avoid nepotism; however, on the contrary, one of his aides derives joy in abusing and insulting the umbrella 'Association using every unprintable words' (Olu 2020).

If Nigeria does indeed have an excellent justice system, as the Vice President, Yemi Osinbajo claims, then how can the Chief Justice of Nigeria (CJN), Justice Ibrahim Tanko Mohammed, on 18 December 2019 throw caution by advising that Muslims should use their numerical superiority in the National Assembly to amend the Constitution of Nigeria, with a view to adding more Sharia contents to it get away un-rebuked? (Forwarded Text 2019). After this blatant utterance, the Chief Justice has not denied or retracted the statement, and the government has NOT called him to order, it means that he was speaking ex abundantia cordis of the government and the Muslim Ummah.

Despite the yearnings, pleas and aspirations of the CAN, there are no Christians heading any of the three arms of government in the administration of Nigeria. This is unheard of in the political history of Nigeria since independence. Is it that there are no Christians worthy or qualified to occupy any of these sensitive positions?

At the present time, $98 \%$ of the members of the National Security Council of Nigeria 'come from one part of the country and people of same faith', implying that Christians are not worthy to hold any of the key appointments but to be relegated 'to play the second fiddle'.

There are lopsided appointments in the polity in favour of one religion and towards a section of the country, which is unconstitutional and violates Nigeria's Federal Character Principle, according to the spirit and letter of Sections 10, 13 (3-4); 15, (2) (d) and (4) of the Constitution. This confirms the popular fear and perception that government is against the Christian population. The non-action of the President to heed the calls by Christians to correct the imbalances of his appointments indicates that he is grossly insensitive to recognise the fact that the country 'belongs to all Nigerians irrespective of their religious, tribal and political beliefs' (Danjuma 2020). The most recent appointments made in the Police Force are good evidence for Christians in the country 
to recognise that the government is on the warpath against the Christians of Nigeria (ElombahNews 2020).

It beats our imagination to reason out why the Head of State of the Federal Democracy would go to Egypt to tell the world that, as from January 2020, there would no longer be visa requirements for Africans to come to Nigeria. Why should such a policy be a one-man decision? Except that he has the blessing of the Nigerian Fulani oligarchs and the insider network of the Fulani in sub-Saharan Africa to give the Fulani rejected and unwanted elsewhere finally what they have been wanting all along; namely, a homeland for their own so that they can flood Nigeria in their millions and, in 5 years' time, Nigeria's demographics would be forever changed (Danjuma 2020). Who doubts that this policy is a subtle effort to alter the racial and religious demographics of Nigeria that will allow the Fulani, Berbers, Tuaregs and Arab migrants into Nigeria to enslave the indigenous Nigerian populations? Is this not a calculated attempt to flood Nigeria with these 'born-to-rule' people whose main objective is to implement the RUGA (Ruga is a Fulani word, which means colony) to the letter, seize Nigerians' lands and insist on Sharia law in the country as the CJN has hinted unchallenged?

Does the Head of State and the cabal around him not recognise that such a self-serving policy will ultimately result in large-scale conflicts, carnage, racial- and religious-strife, and total catastrophe if they do not end this agenda of enslavement and dispossession? (Chief Femi Fani-Kayode, 11 December 2019).

Why are the Fulani Herdsmen, who are largely responsible for the latest waves of violence, allowed to freely roam the southern states, armed to the teeth? Why is the Nigerian Government, if it has no hidden enslavement agenda, not taking determined actions to stop the killings? Gory stories of human carnage fill the air and cry to heaven for divine vengeance; yet, the police would say: 'investigation is ongoing...'; yet at the end of the day, no arrests of the culprits are made. Why nothing has come out till today on the investigation of the murder of Funke Olakurin Fasoranti, the daughter of a Yoruba Chieftain of the Afenifere, a well-known pan-Yoruba social-cultural organisation, which recently happened on Akure-Benin road? Why, if it is not to prosecute their enslavement agenda, are the atrocities explained away as 'driven by desertification, climate change or competition for resources'? If there is no 'hidden agenda' of enslavement, why does the Nigerian Government and leadership abdicate their fundamental duty to look after the most vulnerable citizens and the protection of the Christian communities? (ElombahNews 2020; Yoruba Council of Elders Europe and America 2020).

Do we not hear or know of the horrendous hardship Christians are subjected to in Kaduna, Benue, Plateau, Adamawa and Taraba states, where Christians are being slaughtered like rams by the Boko Haram insurgents who have killed and maimed over 1000 Christians, since the beginning of 2010? Or of their nefarious activities in the
South-eastern states of Enugu and Ebonyi, where Christian clergies have been kidnapped by killer herdsmen whilst the security agencies appear to be complacent and powerless or unwilling to arrest the culprits (Christian Social Movement of Nigeria [CSMN] 2020; Yoruba Council of Elders Europe and America 2020)? Does this not prove that the government of the day lacks the political will to deal with these criminals? This, amongst other things, explains why the Hate Speech Bill is being bandied about and exaggeratedly being urged to be sponsored so that the mouths of Christian religious leaders would forever be gagged (Oyedepo 2019).

Even though Muslims live in those states of violent barbaric killings and senseless destruction of properties occurs, the primary targets are Christians' businesses, houses, and workshops, for instance, as reported in Kaduna and Benue states (CSMN 2020; Yoruba Council of Elders Europe and America 2020). Besides, it is known that some $95 \%$ of those detained by terrorists are Christians, and the government has been paying lip service towards securing their freedom. We now know the case of Leah Sharibu's colleagues is factual. However, the negotiation for the release of Leah, the daughter of a police officer, has dragged on by the government because of her religion (Lowry 2019).

Even the so-called anti-graft war, which has won President Buhari's fame in the international community, is lopsided. The selective approach adopted by the government and its agencies Economic and Financial Crimes Commission, and Independent Corrupt Practices Commission (EFCC, ICPC) to fight corruption in Nigeria is largely targeted against Christians who had held or hold any enviable designations in the present administration.

What about the infelicitous event that was reported at the Abuja Federal High Court on 6 December 2019 when the operatives of the State Security Service (SSS) wilfully invaded the Court under the jurisdiction of Justice Ijeoma Ojukwu to re-arrest an activist Christian Publisher of Sahara Reporters, Mr. Omoyele Sowore and Olawale Bakare, after 124 days of incarceration for calling for a nationwide protest against bad governance. If the President and his Vice decry to re-arrest these men, who then is ruling Nigeria? (http://www. premiumtimesng.con/news/headlines/367459). The Nigerian Government cooked up accusations of treason, money laundering and insulting Buhari against them.

All these deprivations are enslavement policies of the government, and they prove the subtle agenda of Islamisation and nepotism, the government is pursuing in order to deface the presence of the Christian religion in Nigeria. As many of the policies of the current government fail to be implemented according to the spirit and letter of the Constitution, Christians in Nigeria fear a dawning era of enslavement, and the lack of a sense of belonging for themselves and their children. What else can enslavement mean when in a democracy with a respectable Constitution that stipulates in its Art 10, 2 that the nation has no national religion and that 
all religions have equal right to exist where no one shall be persecuted, oppressed, enslaved and treated unjustly on account of her or his belief or faith. If there is no will and brazen intention to enslave the Christian population of Africa's most populous nation by the powers that be, how does one understand the behaviour of government and the ruling cabal, which thrives on the repression of freedom of speech in recent times in Nigeria? What enslavement is greater than that? For the Nigerian Christians, Paul's intervention on behalf of Onesimus behests them to rise up and challenge the Head of State to come to his senses, to embrace wisdom and courage to govern the country as the Father of all and sundry in the nation. For instance, Kukah (1999) reacting to the activities of Desmond Tutu (1994) and other South Africans in their fight against apartheid called the Christians in Nigeria to wake up in the task of confronting the challenge in the nation or wake up 1 day and see that it is no longer safe to be called a Christian in their country.

\section{Methodology}

We read Philm vv. 8-18 from the context of this increasing sour relationship between Muslims and Christians in Nigeria. The opinion of oppression scholars like Cone can be identified with the fact that it is becoming apparent that, in modern Nigeria, there is no political will on the part of the current rulers to promote harmonious living. The guess is that they wish to mastermind the enslavement and oppression of the Christian population (Cone 1975:120) The situation calls for an urgent employment of the biblical principles that are rooted and derived from the liberation-theological approach, which promotes deliverance from oppressions by the mighty. This will make the crave for social justice as a worthwhile arrowhead in doing contextual biblical exegesis (Knight 1999:349-359; McGovern 1983:461-472; Shannon 1978:141). If slavery, human trafficking and the enslavement of other persons, groups, or rather any ethnic or indigenous peoples include the overt denial of their God-given freedom as revealed by the current Nigerian political terrain where there is an absence of accountability, good governance and social justice, the hallmarks of a democracy, then liberation mediated through the liberation-theological investigation is ad rem and considered a relevant tool to process this study (Boff 1979:100-132), The liberation-theological method, which has been developed in Latin America since the 1960s (Boff 1979:100-113; Cone 1970:120-125; McGovern 1983:461-472), is still adjudged relevant in Africa, especially Nigeria, where a novel style of oppression and slavery is prevalent (Cone 1970:120-125; McGovern 1983:466-472; Lohfink 1987). The seminal works of biblical scholars, such as B. de Las Casas, who had vehemently condemned the dispersion, enslavement and forced Christianisation of the First nations, gained so much acclaim and won many adherents. De la Casas' views of liberation, which were inspired by the Exodus, still have implications for the liberation of other oppressed peoples of the Earth (Cone 1975:108-109). In this light, we wish to adopt the liberation-exegetical theological method to read the letter to Philemon vv. 8-22 amongst Africans, especially Nigerians, in order to expose the text's central message and, from there, to see how lessons gleaned from the letter can be used to address the Nigerian contemporary situation of a developing hidden agenda in its various ramifications. The grand purpose observed is to inexorably enslave the Christian population (Mailafiya 2020a, 2020b; Yoruba Council of Elders Europe and America 2020). Besides, we challenge the text as we re-read it to bring out (ex-egomai) the core lesson in the verses, which can help us creatively speak through Paul to address the issues of oppression and pauperisation of the real ethnic peoples of Nigeria by migrant, stateless, and homeless Fulani leaders and their herdsmen who have, with impunity, turned themselves into terrorists, killers and land grabbers in Nigeria.

We know that the Gospels present Jesus as a poor man who, with his inauguration of the Reign of God to the poor and the downtrodden showed how God fights on behalf of the oppressed and the exploited. According to Jesus' message of sisterhood, brotherhood and solidarity with the marginalised in the society, which is superbly enhanced by his resurrection (cf. Eph 4:8ff; Gal 3:28-29) and which is really lived out in the pages of Luke-Acts by the early Christians living on goods in common corroborates Jesus' last minute good news 'it is finished' on the cross (Jn 19:30). Previous studies on the Christian Bible allow us to recognise that many of the books of the Bible lay great and sustainable emphasis on the priority of the liberation of the enslaved (Swetnam 1984:376-380). Is it not the spirit of revolution that inspired the Maccabean sons to resist and challenge the hegemonic oppression of the Persian tyrants against the people of God? From the Maccabean uprising to the Ezra-Nehemiah patriotic reconstructions, the revolutionary spirit inspired by the scriptures lives on and no doubt impacts on today's call for redemption and the consequent physical and spiritual reconstructions that prosper the people of God (Kukah 1999:197). How about the spirit of revolution in the pages of the NT? Is it not from the accounts in the NT narratives that we are confronted with Jesus' denunciation of the ravages of the Herods of his day or do we merely pay lip service to the provocative motifs and the liberating spirit encapsulated in his parables, especially in the Sermon on the Mount (Mt 5-7) and in the expostulations of Mary, the Mother of Jesus, in her Magnificat (Lk 1:46-55)? The Magnificat remains a special text with a mother's touch, which cannot but inspire radical revolutions in the public domain, rural and local environments of the past age and of the present.

The lessons are copiously indicative of any of the authoritarian states, alias the wild animals that must come to crash as victory of the oppressed is always certain - victoriacertaest. What the 'slavers' and the oppressors do not seem to understand is that despite the level of sufferings, the oppressed will always keep up their hopes and look forward to the dawn of 'a new heaven and a new earth'. Even though many commentators argue that Paul's letters acquiesce to the prevailing sociopolitical and economic structures and status quo of his day, we believe that Paul's plea or intervention for Onesimus, and 
his willingness to repay and indemnify Philemon for his scam over his master's property, opens a great vista on the importance of building a society where everyone stands free with no fear and receives justice from all forms of man-made oppressive policies (Boff 1974:449-426).

Paul's letter to Philemon assists us to re-read and understand the Bible from the real situation of the experiences of anyone or any people in such situation whether justly or unjustly if the principle of generalisation is aptly applicable here. This study is, therefore, a case of academic exegesis from the perspective of liberation theology that focuses on Philemon vv. 8-22 as one amongst the many representative biblical testimonies that support the liberation of the people of God. Paul's magnanimity in pleading for runaway Onesimus inspires Christians to prosecute liberational revolutions in our days. Philemon 8-22 read from the stance of Christians who live in fear of a formidable and menacing enslavement. In a not-too distant future (as indicated by the light shown by our context of interpretation), there shall be an urgent need for understanding the realities of liberation in terms of political, economic, social and cultural liberation confronting Nigerians and elsewhere in Africa where enslavement is brazen-facedly forced unto the people (Knight 1999:357).

The spirit of liberation theology we derive from reading Philemon vv. 8-22, especially from the:

[T]hree actants, Philemon, Onesimus and Paul does neither attempt to reduce liberation to the political and economic sectors alone, nor does it do it to the spiritual and otherworldly levels, but to one done theologically to affirm the rejection of the separation of the order of creation from the order of salvation of nature, from the supernatural, of history from salvation history. (Knight 1999:352)

For Christians in Nigeria, the liberation they call for is liberation from injustice, fear, religious intolerance and oppression through RUGA and the Visa Free Policy of the powers that be. The praxes of the historical Jesus in the NT, especially in his manifesto enshrined in Luke 4:18-20 draw our attention to Jesus' view of 'a comprehensive revolution in the structure of the world' (Boff 1974, 1979).

J. Sobrino, one of the foremost Latin American liberation theologians, avers that the crass marginalisation of the poor critically leads to their liberation from material and sociopolitical oppression (Sobrino 1978). Direct political revolution in the style of the Zealots is to be perceived through such clergies (20th century disciples of Christ who consider it necessary to address any excess of any administration) like Pope John Paul II, Archbishop Desmond Tutu along with his South African compatriots (Kukah 1999, Szulc 1995). Jesus, however, dared the Jewish religious leaders in Palestine of his day, namely, the authorities - of the Second Temple period who were protected by the Roman state apparatus. He challenged the slavers who smarted under the totalitarianism supported and financed by the powerfully rich Jews, such as the Publicans and great landowners, whose faces are hidden in the storylines of the parables. In many of
Jesus' picture talks, he launched severe critique on the tradition, which blessed and endorsed exploitation and oppression through affirmation of a religious ideology, such as the obnoxious belief that one who is rich is blessed by God (cf. Lk 13:31-32; Nwanguma 2015). Instead of recognising Jesus' project to bring about a world of justice and human rights, he was seriously misunderstood as a subversive figure. He was arrested and illegally crucified by those whose consciences were pricked by his sharp proclamations. The resurrection of Jesus is the pole from which liberation descends inviolably to assure the enslaved and the dispossessed in Nigeria to stand firm in their hope for the dawn of a new horizon (Sobrino 1986:296, cf. Eph 4:8-10, Col 2:14-15).

\section{Exegesis of Philemon vv. 8-18}

The exegesis of these verses will hardly be insightful for our quest if the background to the entire one-chapter book of Philemon is not led bare. As much as we understand, the letter was occasioned by the pity Paul took on Onesimus, Philemon's runaway slave (Adam Clarke 1996, 2006). Onesimus conned and defrauded his master of his property in a world where slaves rendered economic benefits to their owners. The church in Colossae was not founded by Paul himself but probably by Epaphras, one of his disciples. Philemon was a staunch member of that church. As a wellto-do person and a faithful member of the Colossian community with a wide business premises, he offered one of his warehouses to the congregation to meet for their regular congregational worship and assembly. Paul had heard and known all about Philemon's diligence in the faith. Paul converted Onesimus to the faith in the Jesus Movement, and he diligently served Paul. It is during this period that he must have reported to Paul how he had fallen out of favour from Philemon, his master. When Paul had gotten wellinformed of the predicament of Onesimus, and assured of his faith in Christ, he undertook to write to Philemon, a 'brother' pleading with him to receive Onesimus back in his service in the love of Christ and the church (Adam Clarke 1996, 2006). Paul's plea must have been motivated by his great teaching in Galatians 3:27-28 that 'in Christ, there is no slave nor free ...'. The letter from its vv. 8-22 keeps us alert on the evil side of slavery and enslavement of any person or group.

Suffice it to note that, unlike most NT books, including Jude, one will hardly trace Philemon to the OT books by way of tracking the background because there is no quotation or clear reference to such in the letter, although Beale and Carson propose that the letter has its background in the OT and the Jewish culture. This deduction is made from Paul's desire that the slave, Onesimus, should not be stigmatised but be accepted as a brother (Dt 23:15-16). Thus, the Jewish commentary that grew up around such a view in the Rabbinic, Targumic and Qumranic literature (Beale \& Carson 2007:918) invariably attests to this notion. Here, however, unlike the position of Deuteronomy 23:15-16 as already stated above, Paul took back the slave to the owner. We would rather infer 
that he was being personal in his stand, and such marks out his peculiarity as both a Christian and a Jew, particularly in his bid to strengthen the reconciliation between Onesimus and the master, Philemon as to have both get bonded back even more than they had hitherto been (cf. vv. 11-14). Consequently, as Onesimus has become a reliable convert of Paul (cf. v. 19), he wrote not to instruct Philemon 'but to appeal to him out of love (v. 8) ... to receive Onesimus "no longer as a slave but as a brother"' (Hauer \& Young 1994:312), thus, appealing to his relationship with Philemon as a partner (a fellow servant of Christ) and thereupon to receive Onesimus as he would receive him. Hence, the letter is a model intervention on true freedom from slavery for the modern man, be it political, social, intellectual or economic.

Nevertheless, given the antecedent as to the position of things regarding the crime of Onesimus in the then world, Paul, according to Rupprecht (2006:638), had, indeed, let Philemon come under a precarious position. In his words:

Paul must have put Philemon in a precarious position indeed. In pleading for Onesimus without a punishment that was obvious to all, he was confronting the social and economic order head-on. While he does not ask for manumission, even his request for clemency for Onesimus and hint of his assignment to Paul defied Roman tradition. (p. 638)

Paul's bold step in asking Philemon not only to forgive Onesimus but also to accept him as a brother and a worthy fellow to be reintegrated into the society as a free man is worthy of commendation. And, the Pauline position, which eventually gave strong impetus for agitation of freedom for slaves in the 18th century, remains an interesting theme for this study (Nwanguma 2017a:97). To present a coherent and meaningful exegesis of Philemon vv. 8-18, we need to present a formal structuration of the unit generally recognised by commentators as a plea for Onesimus (Rupprecht 2006:639-640). These can be sketched as follows:

Vv. 8-9 - Paul makes the plea on the strength of his apostolic authority

Vv. 10-11 - Paul muses on the imagery of the child-father Relationship

Vv. 12-15 - Paul returns Onesimus to Philemon as 'his own heart' Vv. 16-18 - Paul asks Philemon to forgive Onesimus

For the purpose of this study, concentration will be placed on some verses in the third segment, that is, the unit on the plea for Onesimus' forgiveness (Boring \& Craddock 2009:682).

In vv. 8-9, Paul starts the plea with a reminder of his apostolic

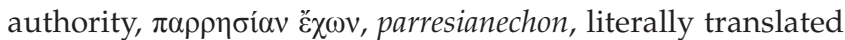
'having outspokenness'. Parresian, according to Bauer, is 'boldness and confidence', 'courage' or 'fearlessness' (Bauer 2000:781). In establishing his apostolic authority with boldness, he was ready to appeal to the value, which is central to the Christian faith, namely, love. In verse 9, the apostle used another term similar to parrфsian, $\pi \rho \varepsilon \sigma \beta v i \tau \varsigma_{\text {, }}$ presbytcs, which primarily means 'old man'. Usually, the word conveys the idea of the vector of authority in the ancient Mediterranean world. For example, in ancient
Sparta, the ruling body was called gerousia (from the word gerœn, 'old man'), and the parallel term to such a word was the Latin senatus (from the word senex, 'elderly person'). In that regard, wisdom and authority were believed to be a sine qua non with old age (Rupprecht 2006:638), although the stress in the instance here was on the apostle's aged and feeble condition considering the force of toioutosœn, which literally means 'being such a one' that is to say in Paul's own words: 'since I am such an old person without much strength to fight but by reason of my age and experience, know that I am still relevant'. Such, indeed, is a lesson to the Nigerian elders. In a traditional Igbo setting, 'the elders cannot stay at home and the goat delivers while tethered', which is amongst other meanings, the elders are expected not to watch things get bad, especially those in a position to speak out particularly on such issues that concern oppression as is happening in the country nowadays. Elders are men of integrity and cannot easily be bought over. For the Nigerian Christians majority who are Igbo people from the south-east and other numerous populations of Nigerians of other ethnicities in south-south, and the Yoruba of western Nigeria, the overwhelming population of Nigerian Christians in the middle-belt, the elders should live up to the expectation of the masses to rise to the occasion to condemn in strong terms the wrongdoings of the government in power. The enslavement agenda in Nigeria is already getting out of hand and calls for the immediate attention of all the requisite stakeholders who are interested in the unity of Nigeria as the Ohaneze Ndi-Igbo and the Afenifere ${ }^{1}$ whose elders have a responsibility to initiate peace moves in order to obviate a coming Amaggedon or blood birth in Nigeria.

In vv. 10-11, Paul wraps his statement with a strong

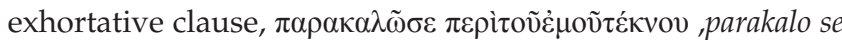
peri touemouteknou ('I am exhorting you concerning my child'), which is committal and bonding. He had entered into a strong relationship with Onesimus, and such was a fatherchild relationship, and about him he was encouraging Philemon to accept him the way he (Paul) would accept him. In Judaism, the figure of the father and child was often used in the mystery religions as illustration of a relationship of teacher and the pupil or leader and the convert (Lohse n.d.:200). Such an imagery was adopted by Paul in this verse to illustrate what Onesimus was to him, as he wrote the conciliatory and recommendation letter to Philemon concerning him whom he saw as his child, emouteknou, ('my child'). The father-child bonding in this verse expresses how he would have necessarily decided to write this conciliatory letter. In v. 11, Paul did a pun on the name of Onesimus. Although a common slave's name, the word onesimos means 'useful' or 'profitable', the meaning of which is identical to that of euchrcrstos, 'useful', an antithesis of achr\&stos, 'useless' in the verse. In this verse, Paul gives out the information that prior to his conversion, Onesimus was useless. However, apart from this sense of the term, Chr\&stos sounds more like Christos, 'anointed one', which amongst the Romans was

1.These two non-political organisations consist of think-tanks and elder Statesmen of the two major southern indigenous populations of the Igbo nation in the east and the Yoruba people in the southwest of Nigeria, who are largely Christians. 
seen as Jesus' name over which there were regular disputes between the Judaisers and the Christian preachers in the Acts of the Apostles (Gundry 1981:229). This dispute came about on the grounds that the Judaisers saw preaching in Jesus' name as flouting their 'orders' according to Luke's account in the Acts on Jesus' name (cf. Ac 5:28a, NIV). As Rupprecht comments, an ancient reader would have thought this play on words much more clever and humorous than it could mean today (Rupprecht 2006:639). Paul's use of this pun at the beginning of his plea on behalf of Onesimus demonstrates his sensitivity and tact, especially considering the radical nature of his request amidst the prevailing customs of the time. Rupprecht further explains that the play on words here was quite apt as opposed to the critical nature of a pun in several regards.

In this unit (vv. 12-15), Paul sends back the now-repented and converted Onesimus as his 'own heart' to Philemon supposedly saying, 'Philemon, to avoid being arraigned to the Law Court, Onesimus ran away from you, his master hoping for a time when you would have re-thought to have him back'. The new leaf Onesimus has turned makes Paul wish to retain him in his own service whilst in prison so that he could help him in the spreading of the gospel. He, however, would not take such a step without Philemon's whole-hearted consent. He re-assures the master that as a now useful convert and a repentant person, Onesimus has become useful to both himself and Philemon as he is now living up to his name as a 'helpful' brother.

In vv. 16-18, this unit bears the central gist of Paul's affability, as expressed in the letter. In these three verses, Paul uses the terms that force one to believe that he climaxes his letter in the verses beginning from verse 16 . Here, two contrasting clauses are used to communicate his intension to his recipient. In his

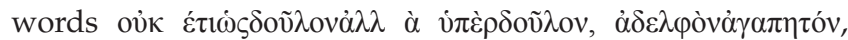
(ouketihosdoulon all' huperdoulon, adelphonagapeton, 'no longer as a slave but more than a slave and a beloved brother' is pregnant with meanings. With the expression, he tried to drive home his points, namely, his plea or pleading truly got grounded on the love of Christ in which all of them share. As already stated, Paul, here, broke open his theme that Onesimus, whom he saw as profitable and useful, should be treated like a brother and not a slave (Aland et al. 2011:565-566). In short, Paul returned Onesimus to his legal or rightful master. The African Bible in its commentary captures the idea in a better form: '[a]s a man, Philemon had a brother for a slave (and) now in the Lord, he has a slave for a brother' (The African Bible 1999:2027). In v. 18, the central lesson of the letter that supports the reason why the Early Christian Church Fathers found it relevant to accept it into the canon is summed up in redressing the cost of Onesimus' wrongdoing (injustice), swindle or scam which Paul pleaded Philemon to 'charge it' it to him. It is a kind of Promissory Note, on which Paul showed his willingness to indemnify Philemon for whatever Onesimus 'might owe him'.

The culture of slavery helped the irreligious as well as religious people to showcase their wealth and rank in society by the number of slaves they had. Onesimus, as a gifted one as his name implies and Paul's pun, would have been one of such who had enjoyed such a status. Besides, as already stated in this work, the Arabians initiated slavery, which has been very much practised in Nigeria, a so-called democratic dispensation that is being demonstrated in different ways. The subtle ways are borne out through feudal politics, and land possession scheme and through the agency of the Miyetti Allah Almagore (Mailafiya 2020a, 2020b; Yoruba Council of Elders Europe and America 2020).

Paul strengthened his plea with a strong bonding term,

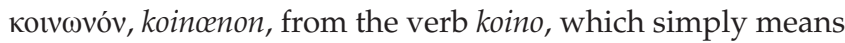
'to make anything common', and as a noun, it means 'fellowship with', 'participation in anything' and 'communicative or cultivating a loving fellowship'. In the context, Paul used it, and especially with it being the accusative noun of the verb " $\chi^{\prime} \varepsilon 1 \varsigma$, echeis, it means 'participating in something with someone' (Zodhiates et al. 1991:1730). This is borrowed from commercial ethos of the day. It is a coinage, which Paul used to draw Philemon's attention to a common value and which both of them shared together in the Christian spirit and the bond that both of them found incomparable. In business parlance, Paul thus appealed to their partnership in Christian ministry, which would always need followership that the repentant runaway slave, young Onesimus, a profitable one, could fittingly be aligned to, should the past be forgotten? Consequently, his request was plainly made known, in his plea: 'welcome him as you would welcome $\mathrm{me}^{\prime}$; in other words, treat him the way you would treat me, which he ideally stated in verse 18. As already indicated, Paul rounded off his request in this verse when he offered to assume any financial obligation that Onesimus would have had himself involved in as he ran away from his master. He might have been able to bear the loss incurred by the running away of a highly skilled and profitable slave whose activities would have fetched Philemon so much fortune. Slaves in that society had no right of their own to anything, including their time or of any economic wealth as theirs. Paul kept his readers in the dark regarding what really happened. This is expressed using the phrases, such as $\sigma \varepsilon$ ì ó $\varphi \varepsilon i ́ \lambda \varepsilon 1$, se $\not$ ofeilei

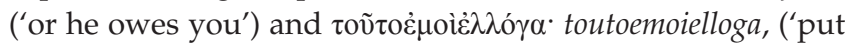
such on my account'). This offer, however, would have, indeed, surprised Philemon. The verb ỏpeí $\lambda \varepsilon 1$ used by Paul was 'persuasive and artistry' as opines Bauer who, like other scholars, believe that Paul was skilful in his choice of words in the letter (Bauer 2000:742). Paul was unswervingly damning the consequence if, however, Philemon's reaction would be contrary to his expectation (Boring \& Craddock 2009:682). Is it of any wonder then why scholars believe that Paul's letter to Philemon was the basic material the later Christian agitators used in their fight against slavery between 18th and 19th centuries, for example, the 1811 Slave Rebellion (alias the German Coast Uprising) at John the Baptist Parish Church in Louisiana in the USA (Al Jazeera 2019). The corresponding word $\dot{\varepsilon} \lambda \lambda \lambda_{\gamma} \alpha$ in the second phrase was such Paul used to cap up his stand regarding his intention to be held accountable instead of the slave. In other words, he was 
saying, 'Philemon, let us end this slavery matter because he (Paul) had sent a clarion call to congregations in Galatia "There is neither Jew nor Greek, slave nor free, male nor female, for 'we' are all one in Christ Jesus"' (Gl 3:28; Manus 1982). 'But if however, you insist, lay the charge on me, let me be bonded for you; Christ paid for me, I can pay for my son, Onesimus'. This commitment of Paul was incidentally sealed in v. 19 where Paul stated, 'I, Paul, am writing this with my own hand. I will pay it back - not to mention that you owe me your very self' (Phlm 1:19, NIV). As already indicated from the beginning of this article, if there could be elders of Paul's kind in Nigeria or pastors like John Wesley (Hildebrandt 1981:77) and his fellow revivalists William Wilberforce, John Venn and Zachary Macaulay (Falk 2011:99), the horrible tragedy of slavery and it's disguised but continued forms might have been a thing of the past.

\section{Current discourse on the impropriety of enslavement in Nigeria}

The African experience of slavery, particularly that of Nigeria, is one of the most pathetic experiences whether in the past or present. In the past, here, we mean slavery in the pre-colonial days, as well as the colonial days (i.e. before the end of slave trade in the 19th century), and the subservient life Africans lived even after the so-called end of slavery. In the present, here, we refer to the prevailing circumstances in the Nigerian nation, as it pertains to the welfare of the citizenry, which is a prototype of what obtains in most other African nations when it was exclusively what may be called precolonial slavery which Hildebrandt calls 'limited slavery' (Hildebrandt 1981:66). However, this could in no way be compared with the experience in the era of 'total slavery' when human beings were treated and marketed as shared commodities. The worth of the slave was assessed and evaluated on the basis of the perceptions people concocted of the individual slave, that is, on whether she or he was strong, smart and charismatic, things were relatively friendly. However, the slavery in vogue, now particularly in the Nigerian society, could be discussed under three main forms: the self-induced slavery, intellectual slavery and what could be termed 'executive slavery'.

The self-induced slavery otherwise known as 'voluntary slavery' as branded by Unegbu (2001:34), consists of those people who submit themselves to slavery because of hardship. Such persons feel that it is better to bond themselves for meals. Just as in an aspect of slavery in ancient Igboland, there was the 'osu caste system' where certain people had to wilfully surrender themselves to any local deity priest to become bonded slaves in the deity's shrine for life (Nnoma 2012:15). This group of slaves do virtually all that transpired during the slave trade in the 18th century when people were bound in chains and shipped to Europe. Today, most youths who feel that their lives in their fatherland are miserable and meaningless resort to travelling abroad to other continents, such as Europe, America and even Asia, for survival. Some even leave for other neighbouring African nations for the same purpose. These people, especially the youths, risk a lot doing these undertakings. For example, lands belonging to families are often sold to raise funds to pay for the journeys. The loss of the land belonging to all is also an aspect of slavery, given the pains such inflicts on the family members. Most pathetic of this are those who travel en route the Sahara Desert through North Africa. As in the slave trade era, dead victims in the process of this en route journey are more than those in chains in those days of slave trade. Over $70 \%$ of females who engage in such journeys end up in austere situations where the money they make are not directly earned by them but by the 'madam' through whom they travelled abroad. About those female modern slaves, Unegbu (2001) writes:

With ladies in this situation their bottoms become their power. Some of their bodies for money, but, as my people say it, condition made crayfish to bend. Many of them become voluntary slaves to hard-hearted men who use these unfortunate ones anyhow to satisfy their erotic desires. (p. 36)

Such ladies are, thus, mere victims who have no option other than to appreciate what fate, so called, offers them as the average African would put it. Their male counterparts are not insulated from such inhuman experiences by being subjected to performing menial jobs abroad, like going as low as being masked as monkeys and other animals to entertain people at zoo, and so on, and this is caused by no other thing than poor leadership. Like the self-made-osu of the ancient Igbos, except for intervention of God by whichever means, their lot remains the same.

The intellectual slavery, on its part, is what one may term undue conditioning of the African thought to only be valid on the basis of Western theories and thoughts, which, in several regards, could only be relevant to their society on such grounds. This plays itself out in all facets of life endeavours, such as social, political, economic, and most pathetically, and even academic. In several ways, the African society has demonstrated subservient tendencies or inferiority complex to the Western world. As a matter of fact, if one would want to exclusively discuss this, there will hardly be enough time and space for deliberation. Quite often, when one reasons along this line, it is always like he is a racist in his approach. That is not the case here. After all, Africa owes the West a lot in its civilisation or anything. However, taking cue from an Igbo adage, Obu nku no na mba n'eghere ha nri ('It is the wood that exists in a place that they use to cook their meals'). In view of this, particularly as it relates to biblical studies, Adamo's (2017) position will be of great use. For him:

Unlike the Western claim, African Biblical Studies does not claim one-hundred percent objectivity. This is because a casual glance at the history of Biblical Studies reveals that there has never been an interpretation that has been without references to or dependent on a particular cultural code, thought patterns, or social location of the interpreter. There is no individual who is completely detached from everything in his or her environment or experience and culture so as to be able to render one hundred percent objectivity in every interpretation. (p. 18) 
This will hardly enable the African scholar to contribute adequately to his society, and the same notion has involuntarily incapacitated the African scholars with regard to originally addressing issues that bother on development as Eurocentric studies will hardly address African matters be it poverty or development, politics, medicine, as well as other sciences. In the same vein, Manus declares that the significance of Liberal Theology in the Nigerian Biblical scholarship', which he believes is the most appropriate in Biblical Studies in African, 'has suffered much neglect' (Manus 2017:40). Why is Liberation Theology so neglected amongst Nigerian biblical scholars? The answer is not farfetched. Intellectual slavery is the word and only one thing is the reason, that is one of the very few Hermeneutical approaches that could be said to be African in essence (Adewale n.d.:26) and as he puts it, it addresses the needs of the oppressed and he Chris Manus, in strong terms, advises that Nigerian scholars have to declare emergency on such issues. He also believes that adoption of Liberation Theology helped black Americans very much in their fight against racism, and that the same was true of South Africans in their fight against apartheid (Manus 2017:41). Although this would be strongly attended to subsequently, low attention to Liberation studies on the part of scholars, either religious or otherwise, is the bane of development in Africa and Nigeria, in particular. In order to deal with this intellectual slavery, heeding to Nwanguma's advice that learning curricular needs to be developed to capture positive Nigerian cultural norms and customs by which the ancestors lived (Nwanguma 2017b:111) will be of immense help.

The 'executive slavery', as holds this study, is that kind of slavery seen in the oppression of the masses by the privileged few in the position of authority. This lends itself out in different ways. It portrays itself in the form of tribalism, nepotism, favouritism and sectarianism seen basically in the lopsided appointments, developmental projects (Ajayi 2020; Ukpong 2020), amongst others, and all these, in one way or the other, are the main causes of self-induced slavery, as discussed by Unegbu (2001:12) earlier in this article. Although the present administration has often blamed all ills in the nation on the past administrations, which has been the trend since 1984 (Akinyemi 2018; Olowolabi 2018), the level of vices in the land now is painfully alarming. In the words of Chris Manus (2017), those in power are described as follows:

In Nigeria, the modern Pharaohs hide under the cloak of political parties, some Ministries and some Directorates of Public Utilities, the Houses of Assembly and Oil Marketers, Police and Customs to deal with us on various socio-economic issues they have failed to promptly attend to. Would anyone believe that in Nigeria the Budget (2017) was just passed nearly six months into the appropriation year? Are the effects on the socioeconomic wellbeing of people not being jeopardized as the SURE-P programmes appear acutely disordered? (p. 41)

The imagery of Pharaoh used to describe the Nigerian leaders in the above quotation is one of the most pathetic. Anyone in religious studies can tell how terrible that could be, let alone those of us in biblical studies who may call to mind the oppression the Egyptian task master meted to the Israelites of old. However, the imagery of Pharaoh is a far cry compared with the Nigerian leaders for just one thing, at least. According to the Exodus story, Pharaoh cared for his people's well-being (Nwanguma 2019). This cannot be said about Nigerian leaders; thus, the comparison can only be apt where reference is just to oppression and denial of the basic needs of the people on the part of the leaders. Averagely, any Nigerian or anyone who is on the news, even far away from Nigerian borders, could tell what transpires in the national life of Nigerians. For instance, the imagery of Pharaoh suggests gross oppression and denial of people's freedom as already noted. This uncaring, oppressive and irresponsible character of the political office holders has eventually trickled down to all facets of leadership in Nigeria, whether amongst those in public sectors or the private sectors of any stature. Here, Hussien Alatas must highly be adjudged right when he said '[w] $\mathrm{w}$ ] power, the fool's values become the people's values' (Alatas 2019, in a lecture at Delta State Universtiry, Abaraka). Depending on anyone's sphere of influence, whether as a prefect in secondary school or just a head amongst unskilled workers in factories, and so on, oppression ensues. These oppressive practices play itself out even amongst friends, children in school, and so on. It is a matter of identifying who you can conveniently ruthlessly deal with, the oppression starts. The harassments of the police and other government functionaries on the roads have become such that no one would want to talk about. Nigerians in one way or the other have become slaves in their own country.

Most pathetic of it all are the activities of the herders across the nation (Mailafiya 2020a, 2020b; Yoruba Council of Elders Europe and America 2020). Both print and electronic media, including the social media, are agog with writings and comments about them. For the sake of this work, response of the Yoruba Council of Elders in Europe and America on June 1,2020 to the menace suffices for the justification of discussing their harassments, attacks and oppressions under this subject matter. In their five-page letter to the Secretary General of United Nation, the following excerpt is germane:

The Yoruba Council of Elders in Europe and America is using this medium to inform the United Nations of the state of affairs in the Federal Republic of Nigeria and the need to intervene urgently to save a situation of potential genocide. Intelligence available points at genocide about to happen on a scale never known before, executed by armed people with logistics back up and positioned strategically around the country. Urgent and decisive action of the United Nation Secretariat, the United Nations Assembly, and United Nations Office on Genocide Prevention and the Responsibility to Protect is required to save lives of millions of Nigerians. (Yoruba Council of Elders 2020:1)

The text above is, in part, the introductory part of the letter to the United Nations, acquainting the organisation of the urgent need to come to the rescue of the country. The intent of the letter is, however, highlighted and discussed in the body of the letter and the same is discussed herewith. Also, in part, the background of the letter reads: 
Several cases of major assaults and onslaughts against Yorubas have been reported to the knowledge of Yoruba Council of Elders Europe and America, in which victims narrated their experiences and that of their families in the hands of Fulani herdsmen. A popular example is the case of Former Secretary to the Government of the Federation in Nigeria, Chief OluFalae who suffered financial loss on his invaded farm, was kidnapped with ransome demanded, and with his worker killed following repeated and incessant invasion of his farm by Fulani Herdsmen. In March 2018, the Former Minister of Defence in Nigeria, General Theophilus Danjuma (rtd) specifically stated that communities attacked by herdsmen in the country need to rise up to defend themselves. He emphasised that it would be suicidal for the people to continue to rely on the armed forces to defend them, and in his words 'They (government security forces) collude with the armed bandits that kill people, kill Nigerians; they facilitate their movement; they cover them'. Former Head of State Chief Olusegun Obasanjo recently in his public speech itemized ongoing agenda of Fulanisation and Islamisation of Nigeria. (Adamu \& Ononuju 2020 Yoruba Council of Elders 2020:1)

The ordeal of distinguished Nigerians who have either been directly affected by the herders' activities or made their observations known at different time periods are captured in the above quotation, which was the background to their letter. The quotation is self-explanatory and needs no additional comments. Further to this, the document in its background segment adds that an effort was made by The British House of Commons in their document of 27 November 2018 titled 'Armed violence against farming communities in Nigeria', to portray the insidious activities of some government functionaries in their efforts to frustrate attempts at stopping insurgencies. In this document, Mrs. Hamsatu Allamin, founder of Maiduguri Allamin Foundation for Peace, claims that members of Boko Haram were ready to drop their weapons, but government stakeholders benefiting from the insurgency were deliberately prolonging the terrorism. The British House of Commons' document, according to the Elders' letter, 'established that a major cause of this violence was the competition between mainly Muslim pastoralists and largely Christian farmers over land and natural resources. (Commons Debate packs CDP-2018-0257' Yoruba Council of Elders 2020:2).

Other items discussed in the letter include a report by the Amnesty International, and what the association calls escalation. In Amnesty International report titled Nigeria: The harvest of death - three years of bloody clashes between farmers and the herders - December 2018, three things were in focus. Amongst them are (1) how the government's inaction fuels impunity, resulting in attacks and reprisal attacks with at least 3641 people killed between January 2016 and October 2018, 57\% of which in 2018; (2) evidence showing that security forces received information about impending attacks, and in some cases, came in contact with attackers, but did nothing to stop or prevent the attacks; (3) and the report that at least seven cases where security forces were aware of attacks and did nothing (Yoruba Council of Elders 2020:2) was equally stated.
In the 'escalation' segment of the letter, several issues were also raised. Firstly, the letter asks whether the government of the Federal Republic of Nigeria is, according to various reports and presented evidence in the letter, still enabling violence against innocent citizens by providing resources and logistical support (land, money, radio frequency and communication equipment) to the perpetrators of the violence. For example, no person has been prosecuted despite the spate of killings in the North-Central. Thirdly, is the benefits from wrong rules designed by authorities, which make innocent citizens additionally weak and vulnerable, forth, reported from the Nigerian media that the Federal Republic Government planned to give Mayetti Allah 100 billion naira which the government tries to deny, but that Mayetti Allah owned up, claiming that it had been approved by the former President Goodluck Jonathan (Yoruba Council of Elders 2020:2). The grand agenda for the plan to give them such money, according to the letter, was to boost their acquisition of arms and other materials needed for the programme of conquering the nation. As stated earlier, the letter is a five-page document by elites of high repute. There was so much to be noted in it. Much effort has been made to capture this in this article in order to substantiate the claim that the situation of things in Nigeria today could only be likened to the slavery experienced in the 18th and 19th centuries and is even worse - a situation where people are experiencing very sad situations and their ordeals are matters to no one. The sequence of events with respect to slavery propensity in the nation's executive slavery gave birth to intellectual slavery, and both gave birth to voluntary slavery, and the same is the trend observed anywhere in the African continent.

\section{Some pertinent observations and suggestions}

As noted earlier, neither Paul nor other Apostles supported slavery, but none resisted it, either for the fear of imperial persecution or organised societal altercation. However, Stamps and his colleagues observed that Paul who represented the early Christian leaders sowed 'seeds of its abolition in Philemon 10,12, 14-17, 21 and thenceforth seeks to regulate it to the benefit of both masters and slaves' (Eph 6:5-9; 1 Tim 6:1-2; Tit 2:9-10; cf. 1 Pet 2:18-19). All truths are parallel. If concerned individuals some centuries ago would assiduously contend against slavery, even where they were not directly affected on the basis of the authors' studies in the Epistles, especially the letter to Philemon, it behoves us to steer or ginger the people of stature today to equally deal with the emerging resurgence of slavery and enslavement as a matter of urgency.

Truths, they say, are always parallel. As Paul, a preacher and clergy of his time, could provide such freedom for a prisoned slave, which according to Hildebrandt (1981:77) was a major motivation to John Wesley, as he instigated most of the abolitionist in 17th and 18th centuries towards 
their struggle against slavery. It must be mentioned that Martin Luther King Jr, who although died in the event but the result is obvious today, got his motivation from this passage. What would we say about Pope St Gregory in his pastoral rule (Pastoral Rule 1974:609)? It is still fresh in the mind of many regarding the intervention of Pope John Paul II (Martin 1990; Szulc 1995; Willy 1988) as regards his contribution towards the achievement of sound democracy in Poland. Desmond Tutu and his South African compatriots will always be remembered for their fight against the apartheid government in South Africa (Kukah 1999:193-197). All these men at one time or the other, in view of their commitment to equality and good governance, fought till they saw results. In the same vein, there is a call here that our people of stature should do likewise. Consequence upon this backdrop, firstly, like William Wilberforce, Abraham Lincoln, John Venn and others through the motivations from concerned clergies such as John Wesley and other clergies of like mind who had sponsored bills that enforced abolition of slavery (Hildebrandt 1981:77), let the clergies of timber and calibre in Nigeria raise such people in their worship places. As those selfless clergies and their selfless cronies amongst their members who thus pin their legs on the ground and fought the slave trade and slavery in their time, the onus is very much on the influential clergies of our day, especially amongst those who have members who are in the parliament, in the executive and in the judiciary to act in whichever way they find necessary to salvage the situation. They may be called names as some of the concerned ones have been hitherto called but that should not discourage them. It took the concerned organisations quite a great deal of time to achieve the abolition of slavery, and so must anyone who is convinced that it is noble to fight against this cankerworm know that it can never be easy. It is certain that those who engaged in the fight against slavery centuries ago were not limited to the clergies and church members. There must have been concerned individuals who may hardly have anything to do with religion but who were empathetic enough to know that any act of inhumanity can hardly be fair. We have such personalities in Nigeria today. The same are hereby called upon to kindly add their voices to get rid of this latent vice. Last but not the least is the need for timely intervention of international bodies such as the United Nations (UN) and African Union (AU), the UN had intervened on such issues in nations around the world, and that of Nigeria should not be a different one, especially now that its President General is a Nigerian. The 'Executive slavery' in Nigeria, especially the extent to which it has escalated, should be a source of concern to the world bodies. Whilst it has to take the academics in Nigeria to deal with intellectual slavery, the executive slavery, for instance, is such that Nigerians only could hardly deal with effectively without the assistance of international organisations.

\section{Conclusion}

This study reveals that Paul's letter to Philemon is a brave and significant Christian treatise with an exhortative and educative implication. Paul admits that slavery is an obnoxious institution and thus reprehensible. Wherever Christians are confronted with the dangers and evils of enslavement, it is sufficient for them to seek liberation through actions of love and not through radical revolutions. Admittedly, the situation in Nigeria may warrant that but Christians should fertilise the public domain with their understanding of agape and Christian principles of love, justice and solidarity that would render any enslavement agenda in Nigeria a contradiction. In Jesus Christ, Christians have no weapons to retaliate or to kill. The Blood of Christ is the great weapon to be used through which any threatening conflict can be silenced, shattered and degraded (Manus 2003, 2010:221-222). What Nigeria needs is social cohesion transformed by mercy. What Liberation Theology envisages in our article however brief for our own part of the world accords very well with the recent pronouncements of Bishop Necodeme Baririgah of the Catholic Diocese of Atakpame in Togo (Swetnam 1984:376-380). According to him, the legal system in Africa 'must essentially be free, just, committed to the Law, concerned with equity, oriented towards social cohesion and naturally, transformed by mercy' (Aciafrica.org/ news/432/africa-trapped-in-its-suffering-justice ... p. 2).

Our strength lies in its diversity, and African leaders must recognise this reality in order to achieve effective justice for all. Paul invites African Christians to accept the differences in fellow brothers and sisters without demonising or seeking at all costs to dominate them. The central lesson of the letter would help all peoples to sue for mutual respect of rights and freedom amongst all Nigerian citizens so as to permit them to actively participate in the affairs of the society regardless of ethnicity, religion and political party (Swetnam 1984). The powers that are ruling the countries must put politics and religion at the service of the common good and 'reach out to build together the conditions for true democracy' (Swetnam 1984).

\section{Acknowledgements Competing interests}

The authors declare that they have no financial or personal relationships that may have inappropriately influenced them in writing this research article.

\section{Authors' contributions}

C.M.U. and C.I.N. contributed equally to this research article.

\section{Ethical considerations}

This article followed all ethical standards for research without direct contact with human or animal subjects.

\section{Funding information}

This research received no specific grant from any funding agency in the public, commercial, or not-for-profit sectors. 


\section{Data availability}

Data sharing is not applicable to this research study as no new data were created or analysed in this study.

\section{Disclaimer}

The views and opinions expressed in this research article are those of the authors and do not necessarily reflect the official policy or position of any affiliated agency of the authors.

\section{References}

Adamo, D.T., 2017, 'African Biblical studies: Realities, illusions and challenge', in J.D. Gwamna, A.O. Dada, \& H. Amolo (eds.), The present state and the future of Biblical studies in Africa: Essays in Honour of Samuel OyiloyeAbogunrin, pp. 14-30, Biblical studies in Africa: Essays
Zenith Book House, Ibadan.

Adamu, F. \& Onnonuju, O., 2020, 'A crossfire on Fmr President Obasanjo's view of the present state of the nation as a failed state', viewed 15 September 2020, from https://youtu.be/1025flHmOGO

Adewale, O.A. n.d., Biblical hermeneutics, Zabak Nigerian, Lagos.

Ajayi, O., 2020, Christian rights agenda calls for review of Buhari's Iopsided appointments, viewed 10 September 2020, from v.vanguardngr.com.

Akinyemi, A., 2018, The ubiquity of corruption and the blame game in Nigeria, article submitted to Nigeria.com, 30 May, viewed 17 September 2020, from https:// www.inigeria.com/1.

Aland, B., Aland, K. 2011, The UBS Greek New Testament. A reader's edition, Greek Bible text: 4th revised edition, running Greek-English Dictionary, Deutsche Bible text: 4th revised edition, running
Bibelgesellschaft, Stuttgart, pp. 565-566.

Bauer, W., 2000, A Greek-English Lexicon of the New Testament and other early Christian literature, 3rd edn., (rev. ed. by F.W. Danker), University of Chicago Press, Chicago, IL

Beale, G.K. \& Carson, D.A. (eds.), 2007, Commentary on the New Testament use of the Old Testament, Baker Academic, Grand Rapids, MI

Boer, H.R., 1976, A short history of the early church, Wm B. Eerdmans, Grand Rapids, MI. Boff, L., 1974, 'Rettung in Jesus Christus und Befreiungsprozess', Conciliuim 10 $449-426$

Boff, L., 1979, 'Christ's liberation versus oppression. An attempt at theological construction from the standpoint of Latin America', in R. Gibellini (ed.), Frontiers of theology in Latin America, pp. 100-132, Fortress Press, Minneapolis, MN..

Boring, M.E. \& Craddock, F.B., 2009, The people's New Testament commentary, Westminster John Knox Press, Louisville, KY, p. 682.

Christian Social Movement of Nigeria (CSMN), 2020, 'GENOCIDE: Fulani Canvasse Murder of All Christians In Nigeria', viewed 30 September 2020 from https:// csmnigeria.org/blog/570-genocide-fulani-canvasses-murder-of-all-christians-innigeria.

Clarke, A., 1996, 2006, 'Philemon', Electronic Database. Copyright @ by Biblesoft Inc.

Cone, J., 1970, A Black theology of liberation, J.B. Lippincott, Philadelphia, PA.

Cone, J., 1975, God of the oppressed, Seabury Press, New York, NY.

Danjuma, T.Y., 2020, 'Fulanis have declared war against indigenous Nigerians and grabbing our lands in the North and Middle Belt and we're playing games with Buhari...the game should be up now', article by Retired General Danjuma urging all indigenous Nigerians from North, South, East and West to face reality, to rise up and defend themselves, read from WhatsApp on 1 August.

ElombahNews, 2020, 8 Major indicators linking FG to Herdsmen, Boko Haram Jihadism - CSO, viewed 01 August 2020, from www.intersociety-ng.org.

Falk, P., 2011, The growth of the church in Africa, Africa Christian Textbooks, Bukuru.

Fani-Kayode, F., 2020, An excellent response by Chief Femi Fani-Kayode @2348181521322 to Aliyu Gwarzo, a response to Aliyu Gwazo, a Fulani racist who boasts of the Fulani oppression of other nigerians, 30th January.

Gundry, R.H., 1981, A survey of the New Testament, Rev. edn., Zondervan Publishing House, Grand Rapids, MI.

Hauer, C.E. \& Young, W.A., 1994, An introduction to the Bible: A journey into three worlds, 3rd edn., Prentice Hall, Hoboken, NJ.

Hildebrandt, J., 1981, History of Christianity in Africa: A survey, Africa Christian Press, Achimota.

Jeal, J.J., Harry, O. \& Maier, W., 2015, Exploring Philemon, freedom, brotherhood, and partnership in new society, SBL Publishing Press, Atlanta, GA.

Knight, D.A., 1999, Methods of Biblical interpretation, Abingdon Press, Nashville, TN.

Kukah, M.H., 1999, Democracy and civil society in Nigeria, Spectrum Books, Ibadan.
Lohfink, N., 1987, Options for the poor: The basic principle of liberation theology in the light of the Bible, The Seabury Press, New York, NY.

Lohse, E., n.d., Colossians and Philemon, Fortress, Philadelphia, PA.

Lowry, L., 2019, 'One year later, Leah Sharibu remains in Boko haram captivity', an article, 19th February.

Mailafiya, O., 2020a, A northern governor is the commander of book haram, viewed 12 September 2020, from https://youto.be/214y0xY102M.

Mailafiya, O., 2020b, Middle belt not just a geographical expression, viewed 13 September 2020, from https://youtu.be/kD7exavr18.

Manus, C.U., 1982, 'Gal 3,28 - A study on Paul's attitude towards ethnicity: Its relevance for contemporary Nigeria', Ife Journal of Religion 2, 18-26.

Manus, C.U., 2003, Christ, the African King: New Testament Christology, studies in the intercultural history of Christianity, vol. 82, Verlag Peter Lang, Frankfurt/Main.

Manus, C. U., 2010, Intercultural hermeneutics: Methods and approaches, Action Publishers, Nairobi.

Manus, C.U., 2017, 'Socio-economic liberation: Roaming the present and future enterprise of Biblical studies in Africa', in J.D. Gwamna, A.O. Dada \& H. Amolo (eds.), The present state and the future of Biblical studies in Africa: Essays in Honour of Samuel OyinloyeAbogunrin, pp. 31-57, Zenith Book House, Ibadan.

Martin, M., 1990, The keys of this Book, the struggle for the world domination between Pope John Paul II, Mikail Gorbachev and the Capitalist West, Simon and Schuster, New York, NY.

McGovern, A.F., 1983, 'The Bible in Latin American liberation theology', in N.K. Gottwald (ed.), The Bible and liberation: Political and social hermeneutics, pp. 461-472.

Nnoma, K., 2012, A Biblical response to the Osu caste system in Igboland: An exegetical study on John 4:1-9, submitted to West Africa Theological Seminary - An Affiliate of the University of Nigeria, Nsukka.

Nwanguma, C.I., 2015, 'Church and society: Examining the Intersection in politics, economics, socio-justice and social welfare', Religion Studies Series 5(1), 248-263.

Nwanguma, C.I., 2017a, 'A missionary study of Paul's model in Christian ministry', in O.E. Alana \& B.O. Igboin (eds.), Akungba Journal of Religion \& African Culture 5(2), 92-107.

Nwanguma, C.I., 2017b, Interplay between corruption and poverty in Africa: A recurring decimal', JORAC: Journal of Religion and Culture 17(1), 92-116.

Nwanguma, C.I., 2018, Biblical missions and church growth strategies: The Nigerian examples, Lambert Academic Publishing, Beau Bassin.

Nwanguma, C.M.J., 2019, 'A mass communication master's degree student on a discussion on the subject matter on Saturday', 22nd of June, Unpublished.

Ogbonna, E., 2012, Lecture on Pauline epistles, Africa Christian Theological Studies, Lagos.

Olowolabi, F., 2018, Blame game: You are also a past leader, take responsibility Campaign for Democracy tell Buhari, article, on Buhari's blame game, viewed 13 September 2020, from dailypost.ng/2018.

Olu, T., 2020, CAN, not Buhari, needs purging of nepotism - Presidency blasts Christian body, an affront by Femi Adesina on Christian association of Nigeria regarding CAN's observation on Buhari's nepotism, viewed 13 August 2020, from https:// thewhistler.ng/can-.

Oyedepo, D., 2019, Crazy hate speech bill is dead, speech by Bishop Oyedepo, presiding Bishop of the Living Faith Church worldwide, at the church's opening ceremony of its annual programme, Shalom, 3 December.

Pastoral Rule of Pope Gregory, 1974, Book 2, vol. 3, The Divine office, Vatican City.

Rupprecht, A.A., 2006, 'Philemon', in T. Longman, III \& D.G. Garland (eds.), The Espositor's Bible Commentary, Rev. edn., pp. 627-643, Zondervan, Grand Rapids, MI.

Shannon, D.T., 1978, 'Theological methodology and the African experience', in C.E. Bruce \& W.R. Jones (eds.), Black theology II: Essays on the formation and outreach of contemporary Black Theology, Vol. 2, Bucknell University Press, Lewisburg, PA.

Sobrino, J., 1978, Christology at the crossroads: A Latin American approach, Orbis, New York, NY.

Swetnam, J., 1984, 'Brazilian Catholics and the Bible', The Bible Today 22, 376-380.

Szulc, T., 1995, Pope John Paul II: The Biography, Scribner, New York.

The Yoruba Council of Elders in Europe and America, 2020, 'A letter to Mr. António Guterres, the Secretary General, United Nations on June 1', about the impending Genocide in Nigeria, Unpublished.

Tutu, D., 1994, The rainbow people of God, the making of a powerful revolution, Doubleday, New York, NY.

Ukpong, C., 2020, Umar to Buhari: You'll destroy Nigeria with lopsided appointment, a letter to Buhari on his lopsided ministerial appointments in favour of the Fulani, viewed 10 September 2020, from offline emutimesng.com.

Unegbu, V.E., 2001, Voluntary slaves, Sheed Printers Nig., Lagos.

Willy, D., 1988, God's politicians: John Paul and the Vatican, Faber and Faber, London.

Zodhiates, S. (ed.), 1991, Hebrew-Greek key word study Bible, AMG Publishers, Chattanooga. 